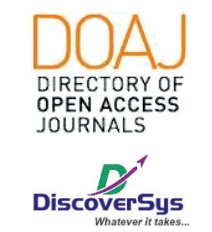

Published by DiscoverSys

\section{Hubungan ASI eksklusif terhadap terjadinya diare akut di Puskesmas III Denpasar Utara periode 2018}

\author{
I Putu Gede Danika Adikarya, ${ }^{1 *}$ Ni Nyoman Metriani Nesa, ${ }^{2}$ Made Sukmawati ${ }^{2}$
}

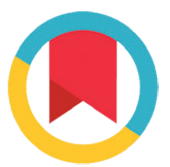

CrossMark

\title{
ABSTRACT
}

Introduction: Diarrhea is still a public health problem in developing countries, including Indonesia, because of its high morbidity and mortality. Breast milk is one of the important factors to reduce mortality and morbidity due to diarrhea. The aim of this study was to determine the relationship of exclusive breastfeeding to the occurrence of acute diarrhea. This research is analytic research with cross sectional method. Method: The study was carried out in Community Health Centre III Subdistrict of North Denpasar from October to November 2018. The research subjects were taken by consecutive sampling. Data analysis used the prevalence ratio calculation and chi square test to determine the relationship between exclusive breastfeeding and the incidence of diarrhea.
Result: In this study the results of acute diarrhea patients in the exclusive breastfeeding group were 17 children and non-exclusive breastfeeding as many as 31 children. Subjects who did not experience acute diarrhea in the excluded breastfeeding group were 28 children and in the non-exclusive breastfeeding group as many as 14 children. The results of statistical analysis showed the value of $p=0.003$ $(p<0.05) P R=0.514 \mathrm{Cl} 95 \%(0.115-0.656)$.

Conclusion: Exclusive breastfeeding has a significant relationship with the incidence of acute diarrhea and is a protective factor for the incidence of diarrhea.
'Program Studi Pendidikan Dokter, Fakultas Kedokteran, Universitas Udayana, Bali-Indonesia ${ }^{2}$ Departemen/KSM IImu Kesehatan Anak, Fakultas Kedokteran, Universitas Udayana-RSUP Sanglah Denpasar, Bali-Indonesia.

${ }^{*}$ Correspondence to:

I Putu Gede Danika Adikarya, Program Studi Pendidikan Dokter, Fakultas Kedokteran, Universitas Udayana, Bali-Indonesia adikaryadanika@yahoo.co.id

Diterima: 12-03-2019

Disetujui: 11-04-2019

Diterbitkan: 01-12-2019
Keywords: Diarrhea, child, breastfeeding, nutrition.

Cite This Article: Adikarya, I.P.G.D., Nesa, N.N.M., Sukmawati, M. 2019. Hubungan ASI eksklusif terhadap terjadinya diare akut di Puskesmas III Denpasar Utara periode 2018. Intisari Sains Medis 10(3): 515-467. D0I: 10.15562/ism.v10i3.434
Latar Belakang: Diare masih merupakan masalah kesehatan masyarakat di negara berkembang termasuk Indonesia, karena morbiditas dan mortalitasnya yang masih tinggi. Air susu ibu (ASI) merupakan salah satu faktor penting untuk mengurangi mortalitas dan morbiditas akibat diare. Tujuan dari penelitian ini adalah untuk mengetahui hubungan ASI eksklusif terhadap terjadinya diare akut. Metode: Penelitian ini adalah penelitian analitik dengan metode potong lintang (cross sectional). Penelitian dilaksanakan di Puskesmas III Kecamatan Denpasar Utara dari bulan Oktober sampai November 2018. Pengambilan subjek penelitian dilakukan secara consecutive sampling. Analisis data menggunakan perhitungan rasio prevalen dan uji chi square untuk mengetahui hubungan antara pemeberian ASI eksklusif terhadap kejadian diare.

Hasil: Pada penelitian ini didapatkan hasil penderita diare akut pada kelompok ASI eksklusif sebanyak 17 anak dan ASI tidak eksklusif sebanyak 31 anak.Subjek yang tidak mengalami diare akut pada kelompok ASI ekskluisf sebanyak 28 anak dan pada kelompok ASI tidak eksklusif sebanyak 14 anak. Hasil analisis statistik menunjukan nilai $p=0,003(p<0,05) R P=0,514$, IK 95\% $(0,115-0,656)$.

Simpulan: ASI eksklusif memiliki hubungan bermakna dengan angka kejadian diare akut dan merupakan suatu faktor protektif terhadap kejadian diare.

Kata kunci: Diare, anak, menyusui. Nutrisi.

Cite Pasal Ini: Adikarya, I.P.G.D., Nesa, N.N.M., Sukmawati, M. 2019. Hubungan ASI eksklusif terhadap terjadinya diare akut di Puskesmas III Denpasar Utara periode 2018. Intisari Sains Medis 10(3): 515-519. D0I: 10.15562/ism.v10i3.434

\section{PENDAHULUAN}

Diare masih merupakan masalah kesehatan masyarakat di negara berkembang termasuk Indonesia, karena morbiditas dan mortalitasnya yang masih tinggi. Secara umum, diperkirakan lebih dari 10 juta anak berusia kurang dari 5 tahun meninggal setiap tahunnya, sekitar $20 \%$ meninggal karena infeksi diare. ${ }^{1}$
Diare akut adalah gangguan saluran cerna yang paling sering dan salah satu penyebab utama dehidrasi pada anak. Gejalanya timbul mendadak, tinja menjadi lebih cair atau lebih berair yang berlangsung selama 7 sampai 10 hari. Penyebab utama diare adalah virus, bakteri, intoksikasi pencernaan dan faktor lainnya. ${ }^{2}$ Faktor lain 
penyebab diare adalah sumber air, ketersedian jamban, imunisasi campak, imunisasi rotavirus, cuci tangan dan sanitasi makanan.

Air susu ibu (ASI) merupakan salah satu faktor penting untuk mengurangi mortalitas dan morbiditas akibat diare. Bayi yang tidak mendapat ASI eksklusif dan tidak mendapat ASI sampai umur 23 bulan sangat berpengaruh terhadap peningkatan morbiditas dan mortalitas akibat diare di negara berkembang. ${ }^{3}$

Efektivitas ASI dalam mengendalikan infeksi dapat dibuktikan dengan berkurangnya kejadian beberapa penyakit spesifik pada bayi yang mendapat ASI dibanding bayi yang mendapat susu formula. Penelitian oleh WHO membuktikan bahwa pemberian ASI sampai usia 2 tahun dapat menurunkan angka kematian anak akibat penyakit diare dan infeksi saluran napas akut. ${ }^{4}$

Berbagai faktor perlindungan ditemukan di dalam ASI, diantaranya adalah antibodi IgA sekretori (sIgA). Imunoglobulin A sekretori akan menghambat paparan mikroorganisme pada saluran cerna bayi, sehingga membatasi masuknya bakteri ke dalam aliran darah melalui mukosa (dinding) saluran cerna. Pada saat ibu mendapat kekebalan pada saluran cernanya, kekebalan di dalam ASI juga terangsang pembentukannya. ${ }^{3}$

Pemberian ASI eksklusif dapat menurunkan risiko anak dirawat karena penyakit infeksi pada usia di bawah 1 tahun. Khusus untuk penyakit diare yang disebabkan oleh infeksi, terlihat adanya hubungan langsung antara pola pemberian ASI dengan menurunnya insiden diare, persentase hari sakit dan lamanya episode diare. ${ }^{5}$ Pemberian ASI eksklusif terbukti menurunkan angka kejadian rawat inap sebesar $53 \%$ per bulan. Pada pemberian ASI non-eksklusif kejadian rawat inap akibat penyakit infeksi hanya menurun sebanyak $31 \%{ }^{6}$

Dari penelitian-penelitian sebelumnya didapatkan bukti bahwa ASI beserta zat imun yang dikandungnya berperan dalam menurunkan kejadian infeksi pada anak yang mendapat ASI ekslusif dibandingkan dengan anak yang tidak mendapat ASI eksklusif. Air susu ibu ekslusif juga dapat menurunkan insiden diare akibat infeksi dan memperpendek lamanya episode diare. ${ }^{5}$

Survei demografi dan kesehatan Indonesia pada tahun 2007 menunjukkan bahwa kurang dari satu dari tiga bayi di bawah usia enam bulan diberi ASI eksklusif. Dengan demikian tingkat proteksi ASI untuk melindungi anak dari penyakit diare khususnya diare akut juga perlu dipertanyakan. ${ }^{7}$ Penelitian ini bertujuan untuk mengkaji hubungan dari pemberian ASI eksklusif terhadap kejadian diare akut pada anak.

\section{METODE}

Penelitian ini adalah penelitian analitik dengan metode potong-lintang (cross-sectional), yaitu rancangan penelitian dengan melakukan pengukuran atau pengamatan variabel-variabel dalam penelitian hanya satu kali dalam satu waktu tertentu. Penelitian dilaksanakan di Puskesmas III Kecamatan Denpasar Utara.Waktu penelitian dilaksanakan setelah usulan proposal disetujui sampai besar sampel terpenuhi. Penelitian dilakukan selama periode Oktober 2018 hingga bulan November 2018. Data penelitian dilakukan pengkajian menggunakan kuesioner yang diberikan oleh peneliti, kemudian sampel dicari melalui metode konsekutif. Sampel dalam penelitian ini adalah anak usia 24-36 bulan. Anak dengan penyakit bawaan gastro intestinal seperti penyakit Hirschsprung disease dilakukan eksklusi dalam penelitian ini. Analisis data dalam penelitian ini menggunakan bantuan perangkat lunak SPSS versi 25.0, analisis perhitungan rasio prevalen dan uji chi-square digunakan untuk menelusuri hubungan antara pemberian asi eksklusif terhadap kejadian diare pada anak.

\section{HASIL}

Jumlah seluruh sampel pada penelitian ini adalah 90 sampel.Pada anak yang berusia 24-36 bulan yang memenuhi kriteria inklusi.Jumlah sampel penelitian ini telah memenuhi jumlah sampel minimal berdasarkan perhitungan yaitu 45 orang untuk kelompok ASI Eksklusif dan 45 orang untuk ASI tidak eksklusif. Nilai tengah usia pada subjek yang mengalami diare akut adalah 27,5 dengan range 24-36 bulan dan subjek yang tidak mengalami diare akut adalah 28 dengan range 24-36. Umur pada subjek yang mengalami diare akut yaitu usia terendah adalah 24 bulan dan tertinggi adalah 36 bulan sedangkan usia terendah dan tertinggi pada subjek yang tidak mengalami diare akut adalah usia 24 dan 36 bulan. Pada variabel jenis kelamin lelaki, didapatkan sebanyak 21 subjek (50\%) mengalami diare akut dan sebanyak 21 subjek (50\%) yang tidak mengalami diare akut. Pada jenis kelamin perempuan, ditemukan sebanyak 27 subjek $(56,2 \%)$ yang mengalami diare akut. Jumlah subjek yang mengalami diare akut pada jenis kelamin laki-laki yaitu sebanyak 21 subjek (43,8\%) (Tabel 1).

Berdasarkan variabel sumber air, untuk kelompok yang menggunakan air kemasan diperoleh sebanyak 29 subjek (52,7\%) yang mengalami diare akut dan sebanyak 26 subjek $(47,3 \%)$ tidak mengalami diare akut. Pada kelompok sumber air dari tidak air kemasan diperoleh sebanyak 
19 subjek (54,2\%) mengalami diare akut dan sebanyak 16 subjek $(45,8 \%)$ tidak mengalami diare akut. Pada variabel jamban, dari 90 subjek seluruhnya memiliki jamban, diperoleh sebanyak 48 subjek $(53,3 \%)$ mengalami diare akut dan sebanyak 42 subjek $(46,7 \%)$ tidak mengalami diare akut. Dari hasil penelitian ini, untuk variabel imunisasi campak dari 90 subjek seluruhnya telah mendapatkan imunisasi campak didapatkan sebanyak 48 subjek (53,3\%) mengalami diare akut dan sebanyak 42 subjek $(46,7 \%)$ tidak mengalami diare akut (Tabel 1).

Pada variabel imunisasi rotavirus, untuk kelompok yang mendapatkan imunisasi rotavirus ditemukan sebanyak 9 subjek $(31,1 \%)$ mengalami diare akut dan sebanyak 20 subjek $(68,9 \%)$ tidak mengalami diare akut. Pada variabel cuci tangan dari 90 subjek seluruhnya melakukan cuci tangan didapatkan sebanyak 48 subjek (53,3\%) mengalami diare akut dan sebanyak 42 subjek (46,7\%) tidak mengalami diare akut (Tabel 1).

Tabel 1 Karakteristik Subjek Penelitian

\begin{tabular}{llcc}
\hline & & \multicolumn{2}{c}{ Diare Akut } \\
\cline { 3 - 4 } Variabel & & $\begin{array}{c}\text { Ya } \\
(\mathbf{N}=\mathbf{4 8})\end{array}$ & $\begin{array}{c}\text { Tidak } \\
(\mathbf{N}=\mathbf{4 2})\end{array}$ \\
\hline $\begin{array}{l}\text { Umur (bulan), median } \\
\text { (rentang) }\end{array}$ & & $27,5(24-36)$ & $28(24-36)$ \\
Jenis Kelamin & Laki-laki & $21(50 \%)$ & $21(50 \%)$ \\
& Perempuan & $27(56,2 \%)$ & $21(43,8 \%)$ \\
Sumber Air Minum & Air Kemasan & $29(52,7 \%)$ & $26(47,3 \%)$ \\
& Tidak Air Kemasan & $19(54,2 \%)$ & $16(45,8 \%)$ \\
Jamban & Ya & $48(53.3 \%)$ & $42(46,7 \%)$ \\
Imunisasi Campak & Tidak & $0(0 \%)$ & $0(0 \%)$ \\
& Ya & $48(53,3 \%)$ & $42(46,7 \%)$ \\
Imunisasi Rotavirus & Tidak & $0(0 \%)$ & $0(0 \%)$ \\
& Ya & $9(31,1 \%)$ & $20(68,9 \%)$ \\
Cuci tangan & Tidak & $39(63,9 \%)$ & $22(36,1 \%)$ \\
& Ya & $48(53,3 \%)$ & $42(46,7 \%)$ \\
& Tidak & $0(0 \%)$ & $0(0 \%)$ \\
\hline
\end{tabular}

Tabel 2 Hubungan pemerian ASI Eksklusif dan Vaksin Rotavirus Terhadap Terjadinya Diare Akut Pada Anak

\begin{tabular}{|c|c|c|c|c|c|}
\hline \multirow{2}{*}{$\begin{array}{l}\text { Pemberian ASI } \\
\text { Pemberan ASI }\end{array}$} & \multicolumn{2}{|c|}{ Diare Akut } & \multirow[t]{2}{*}{$\mathbf{R P}$} & \multirow[t]{2}{*}{ IK 95\% } & \multirow[t]{2}{*}{$\mathbf{p}$} \\
\hline & $\mathrm{Ya}(\mathrm{n}, \%)$ & Tidak (n,\%) & & & \\
\hline Eksklusif & $17(37 \%)$ & $28(63 \%)$ & \multirow{2}{*}{0,548} & \multirow{2}{*}{$0,359-0,656$} & \multirow{2}{*}{0,003} \\
\hline Tidak Eksklusif & $31(68 \%)$ & $14(32 \%)$ & & & \\
\hline \multicolumn{6}{|c|}{ Imunisasi Rotavirus } \\
\hline Ya & $9(31 \%)$ & $20(69 \%)$ & \multirow{2}{*}{0,243} & \multirow{2}{*}{$0,090-0,661$} & \multirow{2}{*}{0,006} \\
\hline Tidak & $39(63 \%)$ & $22(37 \%)$ & & & \\
\hline
\end{tabular}

Hasil analisis bivariat ASI eksklusif terhadap kejadian diare akut didapatkan hasil penderita diare akut pada kelompok ASI eksklusif sebanyak 17 subjek dan ASI tidak eksklusif sebanyak 31 subjek. Subjek yang tidak mengalami diare akut pada kelompok ASI ekskluisf sebanyak 28 subjek dan pada kelompok ASI tidak eksklusif sebanyak 14 subjek. Hasil analisis statistik menunjukan ASI ekslusif memiliki hubungan bermakna terhadap kejadian diare akut dengan $\mathrm{RP}=0,514$, IK $95 \%$ $(0,115-0,656)$, yang berarti pemberian ASI merupakan faktor pencegah diare pada bayi. Nilai tersebut menunjukan pemberian ASI Eksklusif menurunkan resiko diare sebanyak 0,5 kali dibandingkan yang tidak mendapatkan ASI Eksklusif. Ditemukan juga nilai $p=0,003(p<0,05)$ yang berarti ASI eksklusif memiliki hubungan bermakna dengan angka kejadian diare akut.

Hasil analisis bivariat ASI eksklusif terhadap kejadian diare akut didapatkan hasil penderita diare akut pada kelompok ASI eksklusif sebanyak 17 subjek dan ASI tidak eksklusif sebanyak 31 subjek. Subjek yang tidak mengalami diare akut pada kelompok ASI ekskluisf sebanyak 28 subjek dan pada kelompok ASI tidak eksklusif sebanyak 14 subjek. Hasil analisis statistik menunjukan ASI ekslusif memiliki hubungan bermakna terhadap kejadian diare akut dengan $\mathrm{RP}=0,514$, IK 95\% $(0,115-0,656)$, yang berarti pemberian ASI merupakan faktor pencegah diare pada bayi. Nilai tersebut menunjukan pemberian ASI Eksklusif menurunkan resiko diare sebanyak 0,5 kali dibandingkan yang tidak mendapatkan ASI Eksklusif. Ditemukan juga nilai $p=0,003(p<0,05)$ yang berarti ASI eksklusif memiliki hubungan bermakna dengan angka kejadian diare akut. Berdasarkan analisis antara pemberian imunisai rotavirus terhadap kejadian diare, didapatkan hasil analisis imunisasi rotavirus diperoleh OR $=0,243$ IK 95\% $(0,090-0,661)$ $\mathrm{p}=0,006$, yang berarti pemberian imunisasi rotavirus memberikan efek protektif terhadap kejadian diare pada anak (Tabel 2).

\section{PEMBAHASAN}

Pada penelitian ini dari 90 subjek sebanyak 48 subjek $(53,3 \%)$ yang mengalami diare akut dan yang tidak mengalamidiare akut sebanyak 42 subjek (46,7\%). Dari seluruh subjek didapatkan sebanyak 45 subjek (50\%) mendapatkan ASI eksklusif dan sebanyak 45 subjek (50\%) tidak mendapatkan ASI Eksklusif.

Dari seluruh subjek didapatkan sebanyak 42 subjek $(46,7 \%)$ berjenis kelamin laki-laki dan sebanyak 48 subjek $(53,3 \%)$ berjenis kelamin perempuan. Penelitian ini sejalan dengan Manmeet ${ }^{8}$ pada tahun 2017 dari hasil analisis didapatkan sebesar 52 subjek $(53,1 \%)$ berjenis kelamin perempuan 
dan sebesar 46 subjek $(46,9 \%)$ berjenis kelamin laki-laki.

Berdasarkan sumber air untuk keperluan memasak didapatkan sebanyak 35 subjek $(38,9 \%)$ bersumber dari tidak air kemasan dan 55 subjek $(61,1 \%)$ bersumber dari air kemasan. Hasil penelitian ini berbeda dengan penelitian Widarini. ${ }^{9}$ Dari hasil analisis data didapatkan subjek penelitian yang menggunakan tidak air kemasan dan air minum dalam kemasan masing-masing sebanyak 62 subjek. Jadi presentase masing-masing penggunaan sumber air minum kemasan dan tidak air kemasan pada penelitian adalah 50\%.

Dari seluruh subjek didapatkan 90 subjek (100\%) memiliki jamban. Karena penelitian ini dilakukan di daerah perkotaan, sehingga ketersedian jamban memadai hasil penelitian ini berbeda dengan Amaliah ${ }^{10}$ dari hasil analisis didapatkan yang tidak memiliki jamban jumlahnya lebih banyak yaitu sebesar 37 subjek (54,42\%) dibandingkan dengan yang memiliki jamban yaitu sebesar 31 subjek $(45,16 \%)$.

Pada penelitian ini didapatkan sebanyak 90 subjek (100\%) telah mendapatkan imunisasi campak. Imunisasi campak berhubungan dengan kejadian diare.Pemberian imunisasi campak pada bayi sangat penting untuk mencegah agar bayi tidak terkena penyakit campak. Anak yang menderita campak sering disertai dengan diare, sehingga pemberian imunisasi campak juga dapat mencegah diare. ${ }^{11}$ Penelitian ini sejalan dengan Kurniawati dan Martini dari hasil analisis didapatkan sebanyak 142 subjek $(92,1 \%)$ mendapatkan imunisasi campak dan sebanyak 12 subjek $(7,9 \%)$ tidak mendapatkan imunisasi campak. Pada penelitian mereka ditemukan bahwa adanya hubungan yang signifikan antara status imunisasi campak dengan kejadian diare akut pada anak balita. ${ }^{12}$

Pada penelitian ini didapatkan sebanyak 29 subjek $(32,2 \%)$ telah mendapatkan imunisasi rotavirus dan sebanyak 61 subjek $(67,8 \%)$ tidak mendapatkan imunisasi rotavirus. Rotavirus merupakan penyebab diare akut berat pada anak balita baik di negara maju maupun berkembang, sehingga imunisasi rotavirus merupakan upaya pencegahan yang paling efektif. ${ }^{3}$

Berdasarkan kebiasaan mencuci tangan orang tua dan balita didapatkan sebanyak 90 subjek (100\%) selalu melakukan cuci tangan. Hasil penelitian ini sejalan dengan Amaliah (2010) dari hasil analisis didapatkan sebesar $54,4 \%$ (37 subjek) melakukan cuci tangan sebelum memberi makan.

Pada hasil analisis pemberian ASI terhadap kejadian diare akut didapatkan hasil anak dengan diare akut pada kelompok ASI tidak eksklusif sebanyak 31 subjek (34,4\%), dan pada kelompok ASI eksklusif sebanyak 17 subjek (18,9\%). Pada penelitian Mohamad $\mathrm{dkk}^{13}$ menemukan hasil yang hampir sama yaitu proporsi bayi yang diberi ASI tidak eksklusif lebih banyak yang terkena diare yaitu $81,4 \%$ dibandingkan yang tidak diare sebesar 28,6\%. Angka kejadian diare pada bayi yang mendapat ASI eksklusif adalah lebih sedikit dibandingkan dengan anak yang tidak mendapatkan ASI eksklusif. Hal ini dikarenakan ASI mengandung komponen-komponen bioaktif yang dapat mencegah bayi mengalami diare. Beberapa dari komponen-komponen tersebut adalah komponen-komponen imun seperti immunoglobin A (IgA) dan Epidermal Growth Factor (EGF) yang mampu memberi perlindungan kepada bayi dari serangan infeksi. Immunoglobin A dapat mengaktifkan sistem komplemen melalui jalur alternatif dan bersama-sama dengan makrofag untuk memfagositosis berbagai kuman yang masuk. ${ }^{14,16}$

Hasil analisis statistik hubungan ASI ekslusif terhadap terjadinya diare akut memiliki hubungan bermakna terhadap kejadian diare akut dengan nilai $p$ sebesar $0,003(p<0,05) \quad R P=0,514$, IK 95\% $(0,115-0,656)$. Hasil penelitian ini sejalan dengan penelitian Manmeet ${ }^{8}$ diperoleh nilai $p$ sebesar 0,002 $(\mathrm{p}<0,05)$, yang berarti adanya hubungan signifikan antara pemberian ASI eksklusif dengan angka kejadian diare.

Pada variabel imunisasi rotavirus diperoleh $\mathrm{OR}=0,243$, IK 95\% $(0,090-0,661)$ sehingga dapat disimpulkan pemberian imunisasi rotavirus memberikan efek protektif terdapat kejadian diare akut. Hasil penelitian ini sejalan dengan yang dilakukan di Brazil oleh Paolo $\mathrm{dkk}^{15}$ dimana ditemukan tingkat penerimaan rumah sakit untuk diare akut adalah 40,8 per 1.000 rawat inap pada periode sebelum imunisasi rotavirus dan turun menjadi 24,9 per 1.000 rawat inap sesudah imunisasi rotavirus.

Keterbatasan dalam penelitian ini adalah bahwa desain penelitian menggunakan rancangan cross-sectional sehingga nilai sebab akibat antara faktor risiko dan penyakit menjadi rendah dan kurang representative untuk dilakukan generalisasi terhadap populasi.

\section{SIMPULAN}

Dari penelitian ini diperoleh kesimpulan bahwa didapatkan hubungan bermakna antara pemberian ASI eksklusif terhadap kejadian diare akut. Sehingga ASI memiliki peranan yang sangat penting terhadap imunitas dari anak dan merupakan 
rekomendasi nutrisi pertama bagi anak dibawah usia enam bulan.

\section{KONFLIK KEPENTINGAN}

Peneliti menyatakan tidak terdapat konflik kepentingan terkait publikasi dari artikel penelitian ini.

\section{PENDANAAN}

Penelitian ini tidak mendapatkan pendanaan dari pemerintah ataupun lembaga swasta lainnya.

\section{ETIKA DALAM PENELITIAN}

Penelitian ini telah mendapatkan persetujuan dari Komite Etik Fakultas Kedokteran Universitas Udayana/RSUP Sanglah Denpasar dengan nomer referensi 2212/UN14.2.2.VII.14/LP/2018.

\section{DAFTAR PUSTAKA}

1. Agtini D, Magdarina. Morbiditas dan Mortalitas Diare pada Balita di Indonesia, Tahun 2000-2007. Jakarta: Kementrian Kesehatan RI; 2011.

2. Radlovic N. Lekovic Z, Vuletic, B, Simic D. Acute Diarrhea in Children. Srp Arh Celok Lek. 2015;143:755-762.

3. Morrow AL, Rangel JM. Human Milk Protection Againt Infectious Diarrhea: Implications for Prevention and Clinical Care. Semin Pediatr Infect Dis. 2004;15(4):221-228.

4. IDAI. Bedah ASI. Jakarta: Balai Penerbit FKUI; 2008.

5. Lopez-Alarcon M, Villalpando S, Fajardo A. Breast-feeding Lowers the Frequency and Duration of Acute Respiratory Infection and Diarrhea in Infants Under Six Month of Age. J Nutr. 1997;127:436-443.

6. Talayero JMP, Lizan-Garcin M, Puime AO, Muncharaz MJB. Full breastfeeding and hospitalization as a result of infection in the first year. Pediatric. 2006;118(3):e92 - e99.
7. Badan Pusat Statistik. Survei Demografi dan Kesehatan Indonesia (SDKI) 2007. Jakarta: Badan Pusat Statistik RI; 2008.

8. Manmeet K. Hubungan Pemberian ASI Eksklusif Dengan Angka Kejadian Diare Pada Anak Usia 6-24 Bulan [Skripsi]. Medan: Universitas Sumatera Utara; 2017.

9. Widarini A. Perbedaan Kejadian Diare Pada Balita Yang Mengkonsumsi Air Sumur Masak Dengan Air Minum Dalam Kemasan Di Wilayah Kerja Puskesmas Pucangsawit Surakarta [Skripsi]. Surakarta: Universitas Muhammadiyah; 2014.

10. Amaliah S. Hubungan Sanitasi Lingkungan Dan Faktor Budaya Dengan Kejadian Diare Pada Anak Balita Di Desa Toriyo Kecamatan Bendosari Kabupaten Sukoharjo. Jurnal Kesehatan Masyarakat. 2010;1(2):6-10.

11. Andrianto P. Penatalaksanaan dan Pencegahan Diare Akut. Jakarta: Penerbit Buku Kedokteran EGC; 1995. p. 5-10.

12. Kurniawati S, Martini S. Status Gizi Dan Imunisasi Campak Berhubungan Dengan Diare Akut. Jurnal Wiyata. 2016;3(2):128-129.

13. Mohamad I, Abdullah T, Prawirodiharjo L. Hubungan Pemberian ASI Eksklusif Dengan Kejadian Diare Pada Bayi 0-11 Bulan di Puskesmas Galesong Utara. Makassar [Internert]. Makasar: Universitas Hassanudin; 2016 [disitasi 10 Januari 2017]. Tersedia di: http://pasca.unhas.ac.id/ jurnal/files/56e3891d45c1cf4d018a4114189ed0df.pdf.

14. Ibrahim TJ, Manoppo JIC, Rompis J. Hubungan Riwayat Pemberian ASI Eksklusif Dengan Kejadian Diare Akut Pada Anak Di RSUP Prof. Dr. R.D. Kandou. Jurnal E-Clinic. 2014;2(1):1-8.

15. Paolo RLP, Rodrigues ABD, Machado BM, Gilio AE. The Impact of Rotavirus Vaccination on Emergency Department Visits And Hospital Admissions For Acute Diarrhea in Children Under 5 Years. Med Bras. 2016;62(6):506-512.

16. Ani L, Suwiyoga K. Traveler's Diarrhea Risk Factors on Foreign Tourists in Denpasar Bali-Indonesia May and August 2013. Bali Medical Journal. 2016;5(1):152-156. DOI:10.15562/bmj.v5i1.284

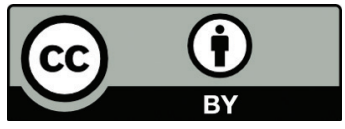

This work is licensed under a Creative Commons Attribution 